\title{
Quantitative mineralogical analysis of small samples of china clay using $x$ ray diffractometry
}

\author{
P D SALT
}

From English Clays Lovering Pochin \& Co Ltd, St Austell, Cornwall, UK

ABSTRACT The quantitative mineralogical analysis of small samples ( $<20 \mathrm{mg})$ of china clay has been investigated using $x$ ray diffractometry to determine kaolinite, mica, quartz, and feldspar. A method has been developed and applied to the quantitative analysis of airborne dust samples and of other small discrete samples. Determinations were made either on samples after collection on a membrane filter or on samples after deposition from aqueous suspension on to a silver substrate. Quantitative analysis was hindered by preferred orientation of the kaolinite and of the mica particles that occurs when using these methods of specimen preparation. Quartz and feldspar were determined direct from prepared calibration graphs. Preferred orientation of the mica particles leads to serious interference with the most sensitive quartz $x$ ray diffraction peak which, if not recognised, will result in an overestimation of the quartz content. Kaolinite and mica were determined from the ratio of their most intense $x$ ray diffraction peak areas to overcome the preferred orientation effects observed for these two minerals. During the investigation, the opportunity arose for comparative measurements of quartz contents of airborne dust samples with the Occupational Medicine and Hygiene Laboratories of the Health and Safety Executive. The mass of specimen examined varied between $0.8 \mathrm{mg}$ and $20 \mathrm{mg}$ and the quartz contents varied between $0.1 \%$ and $1.2 \%$. The comparative results were in good agreement.

Mineralogically, china clay produced commercially in the United Kingdom consists principally of kaolinite and a small amount of mica and trace quantities of quartz and feldspar, the actual composition depending on the commercial grade of the clay. As described by Brindley and Brown, the mineralogy of clays may be determined by $\boldsymbol{x}$ ray diffractometry (XRD)' ${ }^{\prime}$ whereas Salt discusses the application of $\mathrm{XRD}$ in the china clay industry. ${ }^{2}$

With large (infinitely thick) specimens, the instrument response is proportional to the mineral concentration and independent of the specimen mass for given matrix. The mass of specimen extracted from tissue, ${ }^{3}$ or as obtained as the respirable fraction of airborne dust collected in a dust monitor, seldom exceeds $20 \mathrm{mg}$. Such specimens are not of infinite thickness and the instrument response for a given mineral will depend on the actual mass of material examined. ${ }^{4}$ Anderson has reviewed several techniques which may be used to determine silica in environmental samples. ${ }^{5}$

Received 29 October 1984

Accepted 26 November 1984
The present paper discusses some of the problems encountered in determining kaolinite, mica, quartz, and feldspar in small samples of china clay.

During the course of this investigation, the opportunity was taken to compare the technique and method of sample preparation with that uescribed by Pickard et $a^{\circ}$ for the determination of $\alpha$-quartz in the respirable fraction of airborne dust samples.

\section{Materials and methods}

Table 1 lists the reference minerals. The muscovite mica and quartz were prepared by sedimentation from wet ground materials, the conditions being chosen to give $100 \mathrm{wt} \%<5 \mu \mathrm{m}$ equivalent Stokes diameter particle size material. The china clays were all $100 \mathrm{wt} \%<10 \mu \mathrm{m}$ equivalent Stokes diameter and more than $90 \%<5 \mu \mathrm{m}$ equivalent Stokes diameter. The mineral compositions were determined by XRD using infinitely thick "randomly" orientated powder specimens.

Small discrete solid samples and the corresponding calibration standards were examined by XRD as specimens on $2.5 \mathrm{~cm}$ diameter, $0.8 \mu \mathrm{m}$ pore size 
Table 1 Mineralogical composition of reference minerals as determined by XRD using "infinitely" thick randomly orientated specimens

\begin{tabular}{|c|c|c|c|c|c|}
\hline & $\begin{array}{l}\text { Particle size analysis } \\
\text { ( } \boldsymbol{\mu} \text { equivalent Stokes diameter) }\end{array}$ & $\begin{array}{l}\text { Kaolinite } \\
\text { (\% by mass) }\end{array}$ & $\begin{array}{l}\text { Mica* } \\
\text { (\% by mass) }\end{array}$ & $\begin{array}{l}\text { Quartz } \\
\text { (\% by mass) }\end{array}$ & $\begin{array}{l}\text { Feldspart } \\
\text { (\% by mass) }\end{array}$ \\
\hline $\begin{array}{l}\text { China clay (a) } \\
\text { China clay (b) } \\
\text { China clay (c) } \\
\text { Muscovite mica } \\
\text { Quartz } \ddagger\end{array}$ & $\begin{array}{l}100 \%<10,>90 \%<5 \\
100 \%<10,>90 \%<5 \\
100 \%<10,>90 \%<5 \\
100 \%<5 \\
100 \%<5\end{array}$ & $\begin{array}{l}97 \\
92 \\
87 \\
14 \\
-\end{array}$ & $\begin{array}{r}3 \\
7 \\
4 \\
86 \\
-\end{array}$ & $\begin{array}{l}-\overline{0.4} \\
\frac{1}{88}\end{array}$ & $\begin{array}{l}- \\
8 \\
-\end{array}$ \\
\hline
\end{tabular}

*Muscovite.

tOrthoclase.

$\ddagger$ Remainder $x$ ray amorphous.

Selas Flotronics silver membrane filters. These specimens were prepared by the filtration of suitable aliquots of ultrasonically dispersed aqueous suspensions of the material. The actual mass of the specimen examined, which occupied a $2.01 \mathrm{~cm}^{2}$ circular area, was determined to a precision of $\pm 1 \mu \mathrm{g}$ using a microbalance.

The respirable fractions of airborne dust collected in personal dust monitors were examined by XRD direct on the membrane used to collect the specimen. This was a $2.5 \mathrm{~cm}$ diameter, $0.8 \mu \mathrm{m}$ pore size Gelman Metricel DM800 PVC copolymer membrane and the specimen occupied a circular area of $3.80 \mathrm{~cm}^{2}$.

The calibration standards for these specimens were prepared in the same way as for the silver membranes but using PVC copolymer membranes.

All the XRD data were obtained using a Philips PW1050 vertical goniometer mounted on a PW1130 generator and fitted with a graphite monochromator, scintillation detector, PW139- series electronics and a broad focus $\mathrm{Cu}$ anode $x$ ray tube.

\section{Results and discussion}

The quartz reference material was used to prepare calibration graphs of intensity versus mass per unit area. The intensity was calculated from the measured peak height above background and the recorded ratemeter setting. Figure 1 shows the results for each of the three principal quartz diffraction peaks using silver filters. The broken lines are for an infinitely thick specimen, evidently the filter loadings are approaching these values. Figure 2 shows the results for smaller loadings $(<0.25 \mathrm{mg})$ $\mathrm{cm}^{2}$ ) on PVC filters.

Apart from the instrument parameters chosen, the detectable limit for quartz is, as discussed by Crosby and Hamer, influenced by the material of the filter used, organic filters giving higher background levels than silver because of $x$ ray scatter by the former. Using a power of $50 \mathrm{Kv}, 40 \mathrm{~mA}$, the background for the PVC filters was observed to be about five times that of the silver, although the nett peak heights were similar for the three quartz peaks at the same filter loading. The minimum recorder ratemeter setting that could be used with PVC filters was $200 \mathrm{c} / \mathrm{s}$ full scale deflection for the 20.8 and $26 \cdot 6^{\circ} 2 \theta$ lines and $100 \mathrm{c} / \mathrm{s}$ for the $50 \cdot 1^{\circ} 2 \theta$ line, whereas $100 \mathrm{c} / \mathrm{s}$ could be used throughout for the silver filters. Thus when using a tube power of 50 $\mathrm{Kv}, 40 \mathrm{~mA}$, a $1^{\circ}$ divergence slit, an $0.1 \mathrm{~mm}$ receiving slit, and the appropriate recorder full scale deflection settings, detectable limits of $4 \cdot 5,0.9$, and

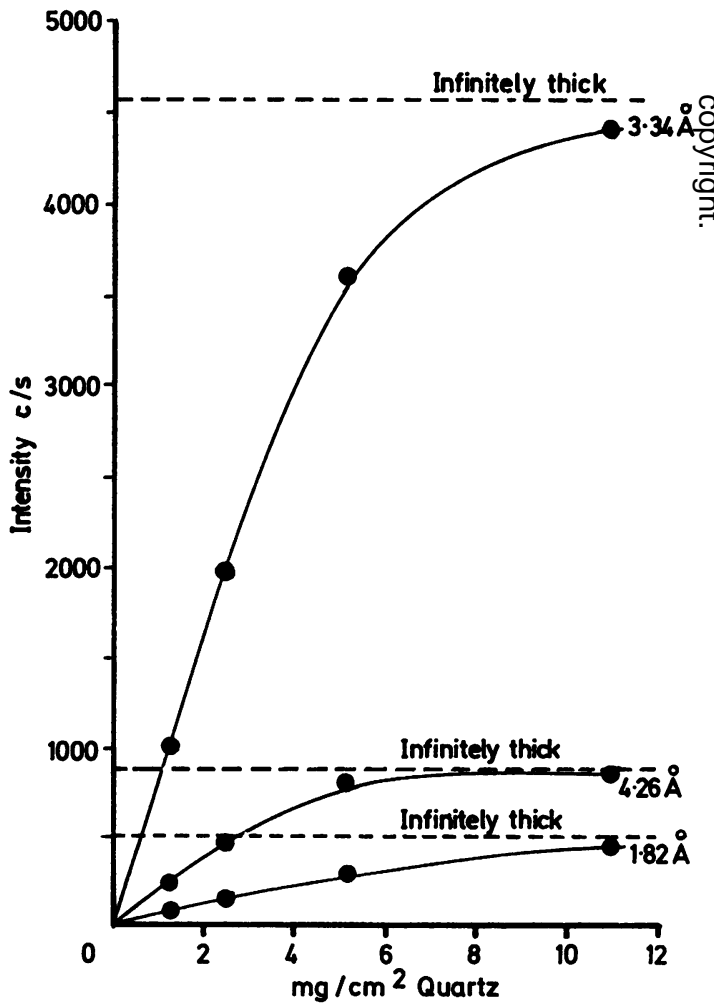

Fig 1 Calibration for quartz on silver filters using $C u K \alpha x$ radiation at $35 \mathrm{Kv} 20 \mathrm{~mA}$ (all ratemeter time constant:1). 


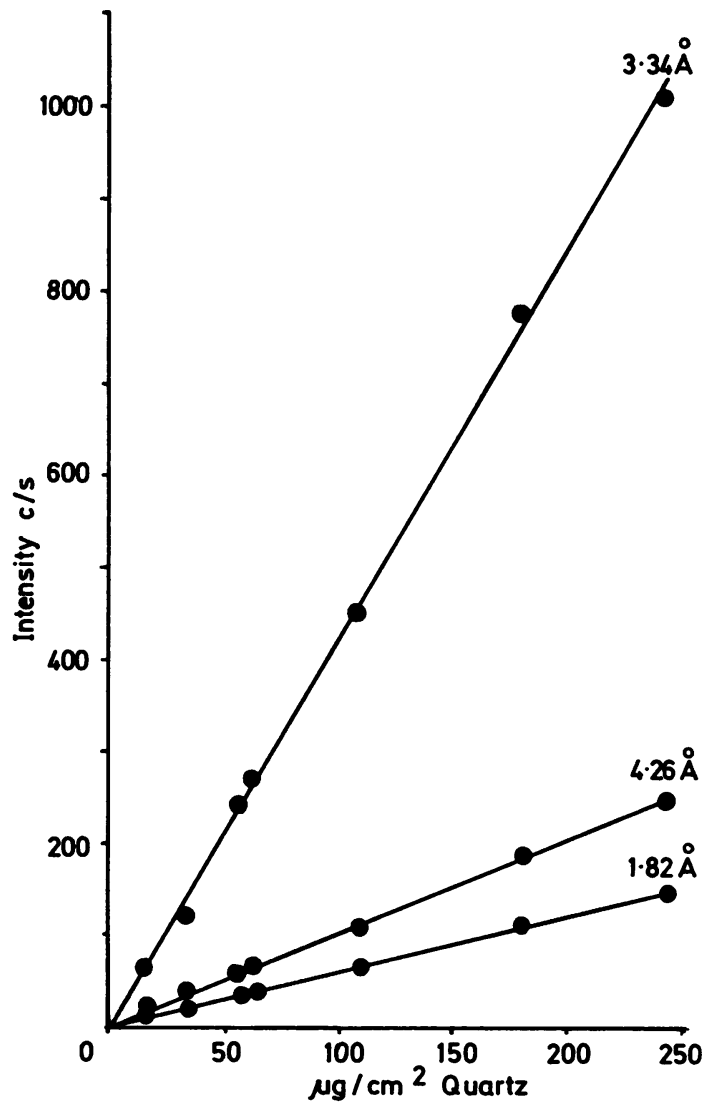

Fig 2 Calibrations for quartz on DM 800 filters using $C u$ $K \alpha x$ radiation at $50 \mathrm{Kv} 40 \mathrm{~mA}$ (all ratemeter time constant:4).

$5 \cdot 3 \mu \mathrm{g} / \mathrm{cm}^{2}$ quartz were obtained for the $20 \cdot 8,26 \cdot 6$, and $50 \cdot 1^{\circ} 2 \theta$ lines respectively when using silver filters. The corresponding values when using PVC filters were $10 \cdot 5,2$, and $10.5 \mu \mathrm{g} / \mathrm{cm}^{2}$ quartz respectively.

Using "randomly" orientated powder specimens of china clay, interference by the $3.33 \AA$ mica reflection on the most intense quartz reflection at $3.34 \AA$ is not significant. Specimens prepared on filters do show preferred orientation because kaolinite and mica are in the form of platey shaped particles. Experiments were carried out to ascertain the magnitude of this effect. Two samples were prepared from the reference minerals (table 1) with the following compositions: (1) $94 \%$ kaolinite plus $6 \%$ mica and (2) $90 \%$ kaolinite plus 5\% mica plus $5 \%$ quartz. Homogeneity was ensured by wet grinding in a micronising mill, filtering, and drying followed by disintegration of the dried filter cake in a small
Cu $K \propto \times$ radiation at $35 \mathrm{Kv}, 20 \mathrm{~mA}$

Ratemeter: FSD $1000 \mathrm{c} / \mathrm{s}$

Time constant: 1

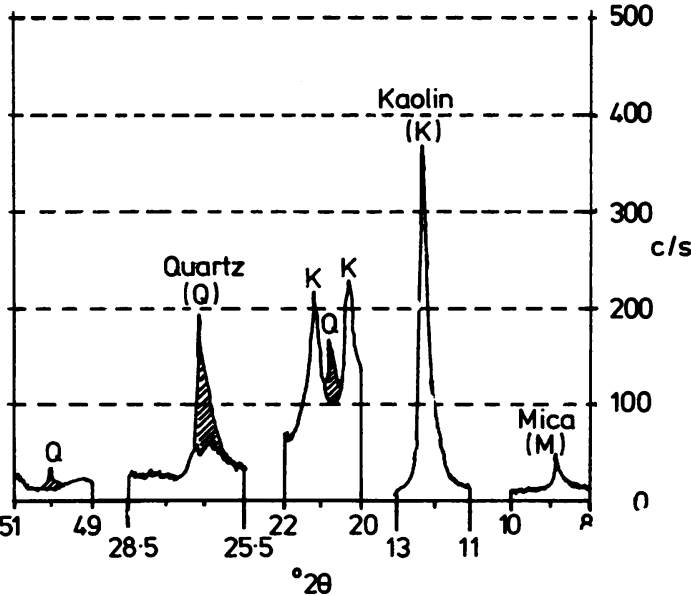

Fig $3 X$ ray diffractometer trace for a bulk randomly orientated specimen containing $90 \%$ kaolin, $5 \%$ mica, and $5 \%$ quartz superimposed on one containing $94 \%$ kaolin and $6 \%$ mica.

laboratory mill. Infinitely thick randomly orientated powder specimens were prepared using the sample holder loading technique of Niskanen. ${ }^{8}$ Superimposed $x$ ray diffraction traces of the principal mineral reflections are shown in fig 3 and those from quartz at $20 \cdot 8,26 \cdot 6$, and $50 \cdot 1^{\circ} 2 \theta$ are readily distinguished. Comparative "thin" specimens $\left(<1 \mathrm{mg} / \mathrm{cm}^{2}\right)$ were next prepared by filtration on to silver membranes and the corresponding $x$ ray diffraction traces are shown in fig 4 . Evidently orientated mica interferes with the most sensitive quartz peak $\left(26 \cdot 6^{\circ} 2 \theta\right)$ in the thin specimens. The 20.8 and $50.1^{\circ} 2 \theta$ quartz peaks are, however, free from such interference. The actual magnitude of the interference from preferred orientated mica on the $26 \cdot 6^{\circ} 2 \theta$ quartz peak is strikingly shown in table 2 . Without recognition of

Table 2 Apparent quartz concentrations for filtered specimens due to mica interference at $3 \cdot 33 \AA$ on the $3 \cdot 34 \AA$ quartz peak

\begin{tabular}{lll}
\hline Reference sample & Mass of sample (mg) & “\% Quartz" \\
\hline (b) & Bulk & 0.4 (actual) \\
(b) & 17.5 & 3.3 \\
(b) & 9.59 & 4.0 \\
(b) & 5.6 & 4.1 \\
(b) & 3.09 & 6.0 \\
(c) & Bulk & 1 (actual) \\
(c) & 20.7 & 2.8 \\
(c) & 10.14 & 3.1 \\
(c) & 5.74 & 4.6 \\
(c) & 3.84 & 3.0 \\
\hline
\end{tabular}

Tube power of $35 \mathrm{Kv}, 20 \mathrm{~mA}$ throughout. 


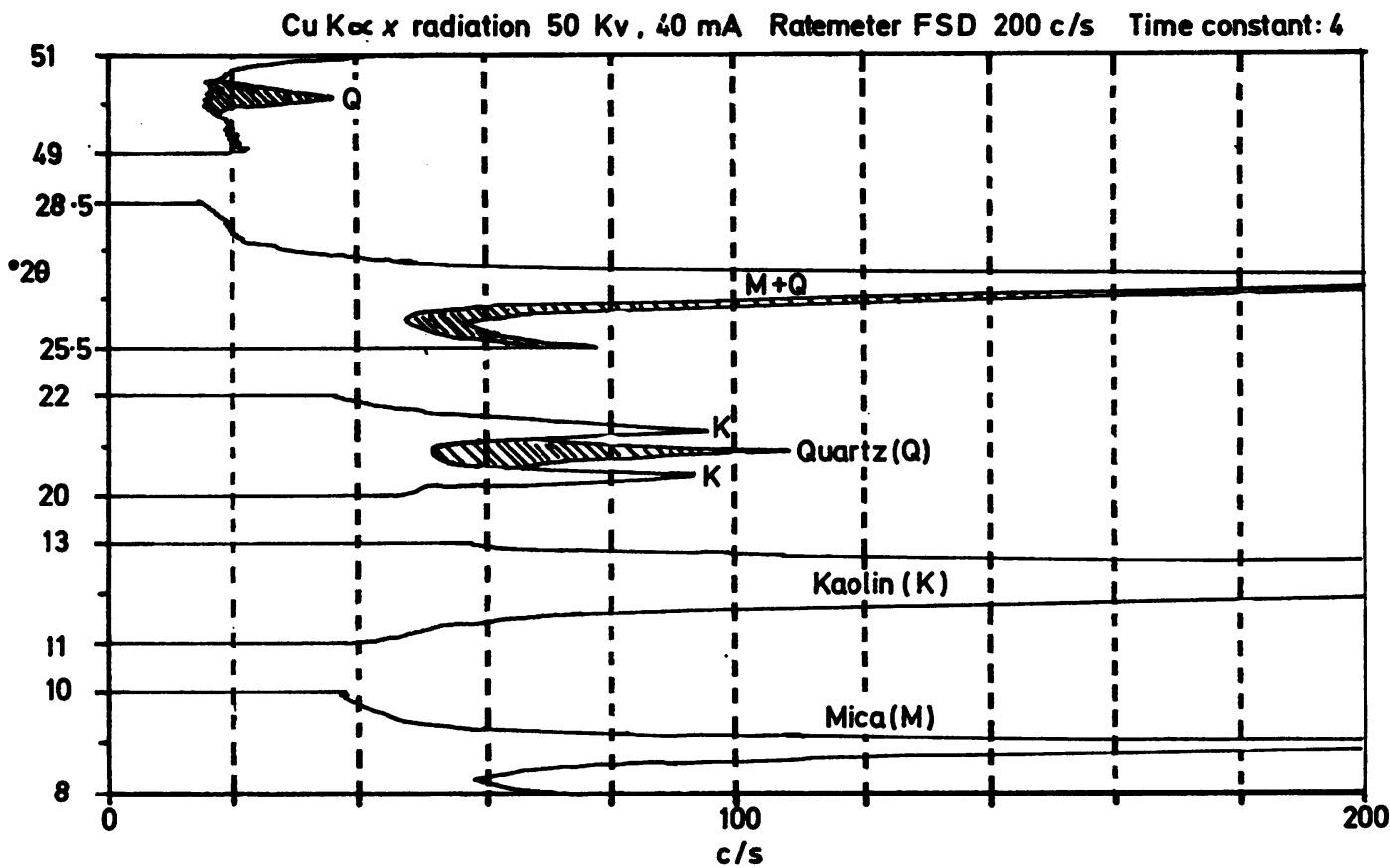

Fig $4 X$ ray diffractometer trace for a $1.7 \mathrm{mg}$ specimen containing $90 \%$ kaolin, $5 \%$ mica, and $5 \%$ quartz on a silver filter superimposed on a second $1.8 \mathrm{mg}$ specimen containing $94 \%$ kaolin and $6 \%$ mica.

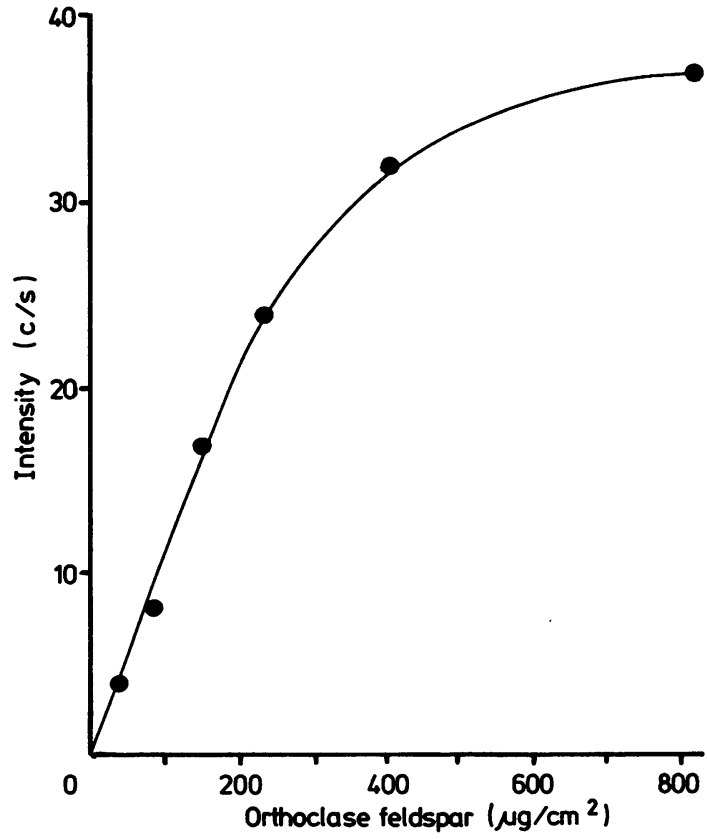

Fig 5 Calibration for orthoclase feldspar on silver filters using $\mathrm{Cu} \mathrm{K \alpha} \times \mathrm{x}$ radiation at $35 \mathrm{Kv} 20 \mathrm{~mA}$ (all ratemeter time constant:1).
$\mathrm{Cu} \mathrm{K} \propto$ radiation and $35 \mathrm{Kv}, 20 \mathrm{~mA}$

Time constant: 1

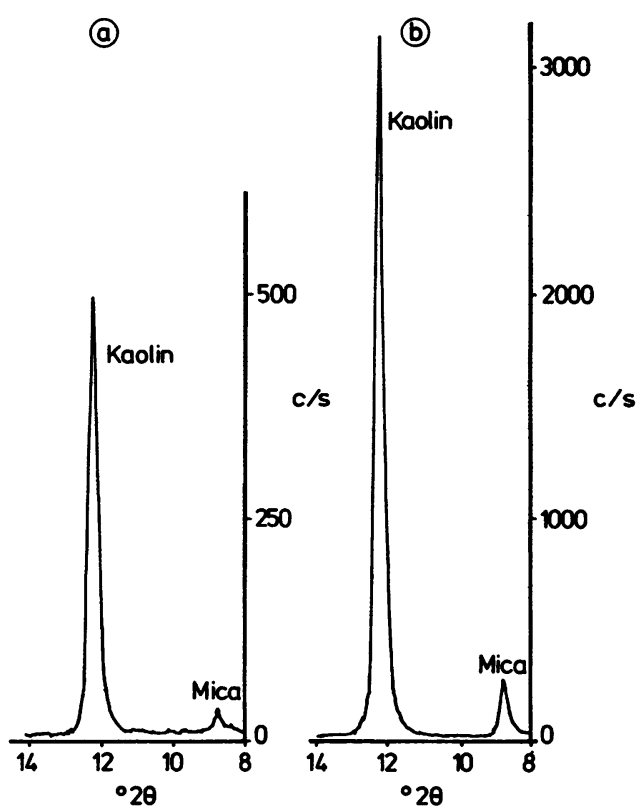

Fig 6 Comparison of mica and kaolinite peaks for (a) random and $(b)$ preferred orientated specimens. 
Table 3 Effect of specimen preparation on $x$ ray diffraction response for kaolinite and mica. (For reference clay (b))

\begin{tabular}{|c|c|c|c|c|}
\hline \multirow[t]{2}{*}{ Specimen preparation } & \multicolumn{2}{|c|}{ Measured nett peak intensity } & \multicolumn{2}{|c|}{ Calculated concentration } \\
\hline & $\operatorname{Mica}(c / s)$ & Kaolinite (c/s) & Mica (\% by mass) & Kaolinite ( $\%$ by mass) \\
\hline $\begin{array}{l}\text { Bulk (random orientation) } \\
\text { Smear (preferred orientation) } \\
17.5 \mathrm{mg} \mathrm{Ag} \text { filter (filtered) } \\
9.59 \mathrm{mg} \mathrm{Ag} \text { filter (filtered) } \\
5.60 \mathrm{mg} \mathrm{Ag} \text { filter (filtered) } \\
3.09 \mathrm{mg} \mathrm{Ag} \text { filter (filtered) }\end{array}$ & $\begin{array}{r}24 \\
256 \\
132 \\
160 \\
120 \\
112\end{array}$ & $\begin{array}{l}484 \\
3104 \\
1984 \\
2112 \\
1768 \\
1072\end{array}$ & $\begin{array}{l}7 \\
7 \\
8 \\
8 \\
8 \\
7\end{array}$ & $\begin{array}{l}92 \\
92 \\
91 \\
91 \\
91 \\
92\end{array}$ \\
\hline
\end{tabular}

Tube power of $35 \mathrm{Kv} 20 \mathrm{~mA}$ throughout.

this effect, the quartz may be overestimated by a factor of 15 .

The feldspar containing reference materials were used to prepare the calibration graph of nett intensity versus mass per unit area (fig 5) using silver membrane filters.

The effect of preferred orientation of kaolinite and mica particles results in increased diffraction intensities for these minerals (fig 6) depending on the degree of orientation. Their concentrations cannot be determined directly from measured peak intensity as can quartz and feldspar, which are not affected in this way. Assuming that \% (kaolinite + mica $)=100-(\%$ quartz $+\%$ feldspar $)$ then the respective kaolinite and mica concentrations are calculated from the ratio of the kaolinite peak area at $12.3^{\circ} 2 \theta$ or 1.25 times the mica peak area at $8.9^{\circ} 2 \theta$ to the sum of these areas relative to the $\%$ (kaolinite + mica). Thus:

$\%$ kaolinite $=$

$\left(\right.$ peak area at $\left.12 \cdot 3^{\circ} 2 \theta\right) \times \%($ kaolinite + mica $)$

(peak area at $12.3^{\circ} 2 \theta \times 1.25 \times$ peak area at $8.9^{\circ} 2 \theta$ ) and $\%$ mica $=$

$\left(1.25 \times\right.$ peak area at $\left.8.9^{\circ} 2 \theta\right) \times \%$ (kaolinite + mica)

(peak area at $12.3^{\circ} 2 \theta+1.25 \times$ peak area at $8.9^{\circ} 2 \theta$ )

Using reference clay (b) the peak intensities for the kaolinite and mica peaks were measured for different types of specimen (table 3 ) with a tube power of $35 \mathrm{Kv}, 20 \mathrm{~mA}$. It is evident that the values for specimens on silver filters vary with sample mass and fall between those of the randomly orientated bulk powder specimen and the "fully" orientated smear. The calculated kaolinite and mica concentrations show that they are independent of the degree of preferred orientation because of the ratio method of calculation used. An interesting point that arises is the degree of orientation occurring for specimens collected in a personal dust monitor. This was investigated experimentally using reference clay (b) to generate a dust cloud in laboratory equipment similar to that described by Pickard et al.$^{6}$ The specimen was collected on a PVC filter and examined by XRD. It was then suspended in water, filtered on to a silver filter, and re-examined by XRD. The results indicated that there was some degree of preferred orientation for the sample on the PVC filter, but not as much as for that on the silver filter.

The precision of the method of preparing samples on silver filters was investigated by examining five replicate specimens each of nominally $4 \mathrm{mg}$ mass. A sample was prepared from the reference materials to contain approximately $95 \%$ kaolinite plus $3 \%$ mica plus $1 \%$ quartz plus $1 \%$ feldspar. The mineralogical composition of this sample as determined for a randomly orientated infinitely thick specimen is given in table 4 together with the results for the five replicate thin specimens. The calculated precisions for the filter specimens are acceptable for this type of sample preparation.

Seven samples of china clay of various grades

Table 4 Precision of XRD analysis for thin specimens prepared on silver filters

\begin{tabular}{llllll}
\hline Replicate No & $\begin{array}{l}\text { Mass on filter } \\
(\mathbf{m g})\end{array}$ & $\begin{array}{l}\text { Kaolinite } \\
\text { (\% by mass) }\end{array}$ & $\begin{array}{l}\text { Mica } \\
\text { (\% by mass) }\end{array}$ & $\begin{array}{l}\text { Quartz } \\
\text { (\% by mass) }\end{array}$ & $\begin{array}{l}\text { Feldspar } \\
\text { (\% by mass) }\end{array}$ \\
\hline 1 & 3.995 & 93.8 & 2.7 & 1.5 & 0.9 \\
2 & 3.879 & 95.6 & 3.2 & 1.4 & 1.5 \\
3 & 4.320 & 95.6 & 2.8 & 1.0 & 0.6 \\
4 & 3.971 & 94.1 & 3.6 & 1.4 & 0.9 \\
5 & 3.998 & 94.0 & 3.3 & 1.5 & 1.2 \\
Mean & 4.033 & 94.5 & 3.1 & 1.4 & 1.0 \\
Standard deviation $(1 \sigma)$ 0.168 & 0.8 & 0.4 & 0.2 & 0.3 \\
\hline
\end{tabular}

Analysis of an infinitely thick randomly oriented specimen gave: kaolinite: $96 \%$ by mass, mica: $2 \%$ by mass, quartz: $1 \%$ by mass, feldspar: $1 \%$ by mass. 
Table 5 Comparison of $x$ ray diffraction results for infinitely thick and filtered specimens for some china clays

\begin{tabular}{|c|c|c|c|c|c|c|}
\hline Clay type \& origin & Specimen type & $W t$ (mg) & $\begin{array}{l}\text { Kaolinite } \\
\text { (\% by mass) }\end{array}$ & $\begin{array}{l}\text { Mica } \\
\text { (\% by mass) }\end{array}$ & $\begin{array}{l}\text { Quartz } \\
\text { (\% by mass) }\end{array}$ & $\begin{array}{l}\text { Feldspar } \\
\text { (\% by mass) }\end{array}$ \\
\hline $\begin{array}{l}\text { Paper coating Cornwall } \\
\text { Paper coating Cornwall } \\
\text { Paper coating Devon } \\
\text { Paper coating Cornwall } \\
\text { Paper coating Cornwall } \\
\text { Ceramic Cornwall } \\
\text { Ceramic Cornwall }\end{array}$ & $\begin{array}{l}\text { Thick } \\
\text { Thin } \\
\text { Thick } \\
\text { Thin } \\
\text { Thick } \\
\text { Thin } \\
\text { Thick } \\
\text { Thin } \\
\text { Thick } \\
\text { Thin } \\
\text { Thick } \\
\text { Thin } \\
\text { Thick } \\
\text { Thin }\end{array}$ & $\begin{array}{l}\overline{14} \cdot 08 \\
\overline{17} \cdot 10 \\
\overline{13} \cdot 77 \\
\overline{12} \cdot 30 \\
\overline{15} \cdot 85 \\
\overline{12} \cdot 31 \\
\overline{16} \cdot 40\end{array}$ & $\begin{array}{l}93 \\
93 \\
92 \\
92 \\
86 \\
90 \\
83 \\
88 \\
81 \\
82 \\
84 \\
88 \\
84 \\
88\end{array}$ & $\begin{array}{r}6 \\
6 \\
7 \\
7 \\
6 \\
5 \\
14 \\
11 \\
18 \\
16 \\
13 \\
10 \\
11 \\
9\end{array}$ & $\begin{array}{l}1 \\
0.6 \\
1 \\
0 \cdot 4 \\
1 \\
0 \cdot 8 \\
1 \\
0 \cdot 2 \\
1 \\
0 \cdot 3 \\
2 \\
0 \cdot 6 \\
1 \\
0 \cdot 2\end{array}$ & $\begin{array}{l}\bar{Z} \\
\bar{Z} \\
\overline{7} \\
4.6 \\
2 \\
0.9 \\
\overline{1} \\
1 \\
1.8 \\
4 \\
2.5\end{array}$ \\
\hline
\end{tabular}

were analysed by XRD in each of two ways. Firstly, as randomly orientated powders (infinitely thick) specimens and, secondly, as less than $10 \mathrm{mg} / \mathrm{cm}^{2}$ deposits on silver filters (thin specimens). The results in table 5 are in excellent agreement, showing that less than $20 \mathrm{mg}$ specimens of china claythat is, $<10 \mathrm{mg} / \mathrm{cm}^{2}$ - may be quantitatively analysed by XRD and give the same results as those obtained from the more normal sample. It should be noted that the paper filler and ceramic clays were wet ground in a micronising mill before analysis to ensure that $100 \%<10 \mu \mathrm{m}$ equivalent Stokes diameter material was examined.

During the course of this investigation, the opportunity was taken to participate in a comparative study for the determination of quartz in the respirable fraction of airborne china clay dust with the Occupational Medicine and Hygiene Laboratories of the Health and Safety Executive. The samples were collected on PVC filters using personal monitors and analysed direct by XRD after weighing. The results, which are for the same specimens analysed in each laboratory, are given in table 6. As described by Pickard $e t$ al, the HSE quartz calibrations were derived from standards collected in a dust chamber. ${ }^{-}$The English Clays' calibrations used, however, were for the $20.8^{\circ} 2 \theta$ peak and, where possible, the $50 \cdot 1^{\circ} 2 \theta$ peak as prepared by filtration from aqueous suspension (fig 2 ). In view of the specimen weights and quartz levels the results are in good agreement.

\section{Conclusions}

Small samples of china clay $(<20 \mathrm{mg})$ may be quan titatively analysed by $x$ ray diffractometry after deposition on to membrane filters.

The kaolinite and mica particles are deposited on the membrane with preferred orientation. Because the preferred orientations occur to the same extent

Table 6 Comparison of quartz values for a series of respirable china clay samples as obtained by the Health and Safety Executive and in English Clays' laboratories

\begin{tabular}{|c|c|c|c|c|}
\hline \multirow[t]{2}{*}{ Sample No } & \multicolumn{2}{|c|}{ Mass on filter } & \multicolumn{2}{|c|}{ Quartz \% by mass } \\
\hline & (mg) & $\mathrm{mg} / \mathrm{cm}^{2}$ & $H S E$ & $E C L P$ \\
\hline $\begin{array}{l}18 \\
97 \\
10 \\
23 \\
16 \\
19 \\
\text { B } \\
\text { D } \\
\text { A } \\
\text { C } \\
30 A \\
31 A \\
32 A \\
33 \\
34 \\
35 \\
30 \\
31\end{array}$ & $\begin{array}{r}1.10 \\
1.02 \\
0.78 \\
1.32 \\
2.34 \\
11.89 \\
11.00 \\
12.37 \\
4.76 \\
1.49 \\
3.19 \\
2.35 \\
2.37 \\
7.12 \\
19.73 \\
2.76 \\
1.46 \\
0.85\end{array}$ & $\begin{array}{l}0.29 \\
0.27 \\
0.21 \\
0.35 \\
0.62 \\
3.13 \\
2.89 \\
3.26 \\
1.25 \\
0.39 \\
0.84 \\
0.62 \\
0.62 \\
1.87 \\
5.19 \\
0.73 \\
0.38 \\
0.22\end{array}$ & $\begin{array}{r}<0.7 \\
1.0 \\
<1.0 \\
1.2 \\
0.4 \\
0.2 \\
0.2 \\
0.2 \\
0.2 \\
<0.5 \\
0.4 \\
0.7 \\
0.7 \\
0.2 \\
0.1 \\
0.6 \\
0.5 \\
<1.0\end{array}$ & $\begin{array}{r}0.6 \\
0.7 \\
<0.7 \\
0.5 \\
0.2 \\
0.2 \\
0.2 \\
0.6 \\
0.2 \\
0.6 \\
0.2 \\
0.3 \\
0.9 \\
0.2 \\
0.2 \\
0.3 \\
0.5 \\
1.2\end{array}$ \\
\hline
\end{tabular}


the quantitative determination of these minerals is unaffected.

Preferred orientation of mica interferes with the most sensitive quartz peak at $3 \cdot 34 \mathrm{~A}\left(26 \cdot 6^{\circ} 2 \theta\right)$ and if not recognised will result in an overestimation of the quartz content.

With optimum conditions, $0.5 \%$ of quartz may be quantitatively determined in $0.4 \mathrm{mg}$ of china clay in the absence of mica interference or $2 \mathrm{mg}$ of china clay when it occurs.

I thank Dr NG West of the Health and Safety Executive for the data shown in table 6, Dr Brian Jepson for his encouragement and for reviewing the original manuscript, and the directors of English Clays Lovering Pochin \& Company Limited for permission to publish this paper.

\section{References}

' Brindley GW, Brown G. Crystal structures of clay minerals and their $x$-ray identification. London: Mineralogical Society, 1980: 305-438. Mineralogical Society monograph No 5 .

${ }^{2}$ Salt PD. X-ray diffraction analysis in the china clay industry. International Laboratory 1981;11:76-86.

${ }^{3}$ Pooley FD. The use of an analytical electron microscope in the analysis of mineral dusts. Philos Trans $R$ Soc Lond $A$ 1977;286:625-38.

- Bradley AA. The determination of quartz in small samples by an $x$-ray technique. Journal of Scientific Instruments 1967; 44:287-8.

5 Anderson PL. Free silica analysis of environmental samples-a critical literature review. Am Ind Hyg Assoc J 1975;36:76778.

- Pickard KJ, Walker RF, West NG. X-ray diffraction and infrared spectroscopy for the analysis of quartz in airborne dust. Ann Occup Hyg (in press).

' Crosby MT, Hamer PS. The determination of quartz on personal sampler filters by $x$-ray diffraction. Ann Occup Hyg 1971;14:65-70.

${ }^{8}$ Niskanen E. Reduction of orientation effects in the X-ray diffraction analysis of kaolin minerals. American Mineralogist 1964;49: 705-14. 